\title{
The Politics of Orthodox Churches in the European Union
}

\author{
Lucian N. Leustean \\ Aston University, Birmingham, UK
}

\begin{abstract}
This article focuses on the political mobilisation of Orthodox churches in the making of the European Union from the 1950 Schuman Declaration until today. It examines the first contacts between Orthodox churches and European institutions, the structure of religious dialogue, policy areas of Orthodox engagement in the European Union, and competing visions of Europe in the Orthodox commonwealth. It argues that the response of Orthodox churches to the institutionalisation of religious dialogue in the European Union (Article 17 of the Lisbon Treaty) is comparable to that of other religious communities. However, the political mobilisation of Orthodox representations in Brussels advances a geopolitical and civilisational dimension which places the Eastern Orthodox world as a competitor to the secular West.
\end{abstract}

\section{Keywords}

Orthodox engagement in the EU; Eastern Orthodoxy and secular West; 'Soul for Europe'; World Council of Churches (WCC); Conference of European Churches (CEC); Charta Oecumenica; Symphonia; Committee of Representatives of Orthodox Churches to the European Union (CROCEU); Commission of the Bishops' Conferences of the European Union (COMECE)

\section{Introduction}

Opening religious offices in Brussels has been akin to an industrial enterprise. In postMaastricht Europe, Christian churches, Muslim and Jewish communities, and Humanist bodies have set up offices in Brussels and Strasbourg representing a wide range of religious and convictional values. The number of faith-based representations have gradually increased after Jacques Delors, President of the European Commission, encouraged a more active reflection in political circles of the role of religious communities and philosophical organisations in the making of the European Union (EU). On 5 November 1990, in a meeting with religious leaders in Brussels he stated the now well-known words that 'If in the next ten years we haven't managed to give a soul to Europe, to give it spirituality and meaning, the game will be up'. ${ }^{1} \mathrm{~A}$ few years later, Delors's words were put in practice in the European Parliament's initiative on 'A Soul for Europe. Ethics and Spirituality' which brought together representatives of Christian, Muslim, Jewish and humanist communities. In 2009, Article 17 of the Lisbon Treaty has institutionalised the dialogue between 'churches, religions and communities of conviction' and European institutions leading to regular meetings between faith-based communities and

\footnotetext{
${ }^{1}$ Hogebrink, Europe's Heart and Soul; Leustean, Representing Religion in the European Union, 4.
} 
organisation and EU officials. ${ }^{2}$ In 2014, 120 religious and convictional organisations were in contact with the European Commission, 82 of which had offices in Brussels. ${ }^{3}$

In the implementation of religious dialogue, Orthodox churches stand out. Orthodox churches, most of which are situated in Eastern Europe and the former Soviet states, follow national lines, at times, working closely together with state authorities in nation-building processes. The Orthodox mobilisation in Brussels has followed a comparable process of accommodating at state and supranational levels with that of other religious communities in Europe. ${ }^{4}$ Other national churches are represented in Brussels (for example, the Church of England and the Evangelical Church of Germany), however, the religious dialogue with Orthodox churches has not only a national dimension but also a transnational one. The Eastern Orthodox commonwealth brings together the faithful across a wide geographical space in opposition to the Catholic and Protestant West. What is 'national' and what is 'transnational' have been a challenge to religious dialogue in the European Union, as the two terms reflect geopolitical interests of both churches and state actors.

This article focuses on relations between Orthodox churches and European institutions from the 1950 Schuman Declaration until today. It examines the emergence of the first contacts between Orthodox clergy and EU officials, the structure of religious dialogue, the Orthodox response to the institutionalisation of religious dialogue, policy areas of Orthodox engagement in the European Union, and competing visions of Europe in the Orthodox commonwealth. It argues that the political mobilisation of the Orthodox churches to Article 17 of the Lisbon Treaty advances a geopolitical and civilisational dimension which places the Eastern Orthodox world as a competitor to the secular West.

\section{Orthodox churches and the European Union: a historical overview ${ }^{5}$}

On 4 April 1989, President Jacques Delors welcomed two metropolitans from the Istanbulbased Ecumenical Patriarchate who visited the European Commission in Brussels. There remains little in the public domain from this meeting and there are no recorded minutes. The meeting was organised by the Forward Studies Unit, an advisory group which was set up by the President the month before, on 8 March, which had under its remit a closer engagement with faith-based communities. The meeting represented the first official engagement between top officials in the European Commission and representatives of Orthodox churches.

The meeting produced little immediate results in the corridors of power in Brussels, however, relations between religious communities and European institutions changed dramatically after November 1990. Delors's encouragement to rethink the nature of the European integration process by addressing issues related to faith and conviction led to many religious communities to open offices closer to European institutions. Orthodox churches followed suit. In 1994, the Ecumenical Patriarchate opened a formal representation in Brussels

\footnotetext{
${ }^{2}$ Article 17 of the Lisbon Treaty states that: 'The Union respects and does not prejudice the status under national law of churches and religious associations or communities in the Member States. The Union equally respects the status under national law of philosophical and non-confessional organisations. Recognising their identity and their specific contribution, the Union shall maintain an open, transparent and regular dialogue with these churches and organisations'.

${ }^{3}$ Leustean, The Ecumenical Movement and the Making of the European Community; McCrea, Religion and the Public Order of the European Union; Mudrov, Christian Churches in European Integration; Kratochvíl and Doležal, The European Union and the Catholic Church; Foret, Religion and Politics in the European Union; Brent and Guth, Religion and the Struggle for European Union.

${ }^{4}$ Byrnes and Katzenstein, Religion in an Expanding Europe; Stan and Turcescu, Church, State and Democracy in Expanding Europe; Davie, Religion in Modern Europe; Noris and Inglehart, Sacred and Secular; Fox, Religion and the State.

${ }^{5}$ Leustean, The Ecumenical Movement and the Making of the European Community.
} 
under the title 'The Liaison Office of the Orthodox Church to the European Union', a title which implied that it aimed to represent the whole Orthodox faithful. The Orthodox Church of Greece was the first to shift away. In 1998, it opened its own office and, in the following years, other churches followed the same pattern. In 2002, the Russian Orthodox Church opened its representation, while, the Romanians and the Cypriots opened their offices the same year, in 2007, a coincidence rather than a joint decision. In addition to official representations which employ staff and clergy in Brussels, renting or purchasing properties, other Orthodox churches found a different approach to communicate with European institutions. The Serbian Orthodox Church has had a representative working directly in the Church and Society Commission of the Conference of European Churches; the Bulgarians worked through their Orthodox Diocese of Western and Central Europe based in Berlin; and after the 2014 Maidan Revolution, two of the main Ukrainian churches appointed bishops to enter in dialogue with European Union, although they do not have permanent offices in Belgium.

The Eastern Orthodox world has occupied a unique place in the engagement of churches engaged with the idea of Europe. After the Second World War, largely placed behind the Iron Curtain, Eastern Europe continued to remain in the thinking of religious and political leaders. Close relations between Christian activism and the concept of a united Europe was evident in the ways in which the contacts between churches and European institutions emerged after the May 1950 Schuman Declaration.

The first organised religious group which engaged in informal relations with European institutions, the Ecumenical Commission on European Cooperation, was set up in Paris in September 1950 and met annually until 1974, bringing together religious leaders and officials working in Paris and Luxembourg. Questions on the role of the ecumenical movement in the early Cold War period let to questions on the use of the word 'ecumenical'. In 1953, the Commission changed its title to the Committee on the Christian Responsibility for European Cooperation. The Committee aimed to provide an assessment of churches' political engagement and many members thought that Greece, as a predominantly Orthodox country which was not under communist control, should be represented by clergy and politicians at its annual meetings. The proposal did not materialise. Relations with Orthodox clergy remained sporadic and, as it will become evident in the following years, it was mainly due to the initiative of local pastors in Brussels and European Community officials interested in the Orthodox world.

An example of irregular engagement with Orthodox clergy was an inter-denominational group titled 'the Christian Vocation in International Civil Service and Diplomacy' organised by Noel Salter, a British official working for the Western European Union in Paris. The group was set up in November 1958 and held religious retreats. At the first gathering in Villemétrie in May 1959, the list of participants included the name of Jean Meyendorff, Lecturer at the Institute of St Sergius in Paris, one of the leading Orthodox theologians of the twentieth century. ${ }^{6}$ A second retreat took place in May 1960 and another theologian from the Institute of St Sergius, Father Boris Bobrinskoy, Lecturer in Dogmatics was present among the participants. It is unclear if Bobrinskoy made any contributions to the discussion, however, his presence showed that civil servants working in European institutions sought from the start to engage with Orthodox clergy in their reflection on the role of churches on the process of European integration. Official meetings between high ranking Orthodox clergy and Western counterparts took place mainly in the context of the World Council of Churches ${ }^{7}$ and the

\footnotetext{
${ }^{6}$ The minutes of the meeting show that John Meyendorff was unable to attend the retreat.

${ }^{7}$ Patelos, The Orthodox Church in Ecumenical Movement; Tsetsis, Orthodox Thought; Sabev, The Orthodox Churches in the World Council of Churches; Limouris, Orthodox Visions of Ecumenism.
} 
Conference of European Churches (CEC) which in the subsequent decades would became highly politicised. ${ }^{8}$

Before the fall of communism the main issue in engaging with European institutions was that for Orthodox churches behind the Iron Curtain, the European Economic Community was an integral part of an ideological bloc. Relations with the West remained only through official diplomatic bodies at state level and international ecumenical channels in Geneva rather than in Brussels and Strasbourg. However, official church relations with the West contrasted with grassroots mobilisation. The increasing number of the Orthodox faithful living in the West and the ecumenical engagement of civil servants working in European institutions meant that Orthodox churches were not too far. In 1963, in Brussels, a mixed-marriage group titled the 'Ecumenical Group of the Fond'Roy Quarter' brought together five families, three of which belonged to different Christian confessions (Catholic, Protestant and Orthodox). Some members of this Group worked in European institutions and local industries and were inspired by the holding of the Week of Christian Unity held at St Anne's Church in the same quarter. The Group began to invite academics and religious leaders to engage with local Catholic, Protestant and Orthodox churches and civil servants. Basile Krivocheine, the Russian Orthodox Archbishop of Brussels and Belgium, and Oliver Clément, Professor at the Institute of St Sergius took part in a number of meetings with local audiences of parishioners and civil servants. An integrated Orthodox presence in the ecumenical milieu in Brussels took place in 1971 with the establishment of the Interecclesiastical Committee of Brussels which enabled Orthodox and Protestant communities to engage regularly on pastoral issues. The grassroots mobilisation in Brussels would benefit the establishment of formal and informal channels of communication between churches and European institutions such as the Consultative Committee of Churches for the European Communities (1964) and the Ecumenical Centre in Brussels (1966). The Ecumenical Centre worked closely with a wide range of religious actors in Brussels, including not only Protestant but also Catholics, as for example, the Jesuit-based Office catholique d'information et d'initiative pour l'Europe (OCIPE).

The pastoral nature of the Orthodox engagement with civil servants in European institutions remained dominant until the late 1980s. After Greece became a member of the European Community in 1981, the Ecumenical Centre in Brussels welcomed the presence of a clergy from the Orthodox Church of Greece at a number of its executive meeting. However, similar to the other Orthodox churches, Greece preferred to retain close relations with the WCC and the CEC rather than with Brussels. President Delors's meeting with the two metropolitans in April 1989 and his emphasis on 'spirituality and meaning' in the construction of Europe radically changed the ways in which Orthodox churches engaged with European institutions. In addition to opening offices, Orthodox churches became part of inter-confessional networks which advanced shared values. During the public debates on the Convention on the Future of Europe and the drafting of the Treaty Establishing a Constitution for Europe in 2001, Orthodox churches worked with the Catholic and Protestant bodies in Brussels advancing the proposal to include 'God' and 'Christianity' in the Preamble of the Constitution. However, the Orthodox engagement with ecumenical partners issuing joint statements on their positions towards the Preamble has to be treated with caution as in many cases they reflected national stances rather than a unified Orthodox view of the future of Europe. This was evident in 2001 at the time of signing the Charta Oecumenica by the Conference of European Churches and the Council of European Episcopal Conferences when the Russian Orthodox Church declared that it was unhappy with the document. ${ }^{9}$

\footnotetext{
${ }^{8}$ The Russian, Romanian and Bulgarian Orthodox churches applied for the WCC membership at the December 1961 New Delhi Assembly. Cavert, On the Road to Christian Unity.

${ }^{9}$ Mey, 'An Assessment of the Charta Oecumenica...'.
} 
In 1999, the ecumenical bodies in dialogue with European institutions in Brussels were integrated into the Conference of European Churches, known as the "Church and Society Commission of the Conference of European Churches'. The physical and spiritual move towards the centre of political power in the European Union, became evident in 2014, when the Conference of European Churches, now representing 116 Orthodox, Protestant, Anglican, and Old Catholic Churches and 40 national council of churches and organisations, transferred its headquarters from Geneva to Brussels. ${ }^{10}$ Despite most Orthodox churches have been CEC members since its establishment during the Cold War period, the Bulgarian Orthodox Church left CEC in 1998 while the Russian Orthodox Church suspended its membership in 2008 due to jurisdictional clashes with the Ecumenical Patriarchate and the recognition of the Estonian Orthodox Church. CEC has attempted to provide a bridge between churches in Eastern and Western Europe and elected Orthodox clergy to its highest leadership positions, such as Metropolitan Emmanuel Adamakis of France (the Ecumenical Patriarchate), who was President of CEC from 2009 to 2013; Father Professor Viorel Ionita from the Romanian Orthodox Church who served as Interim General Secretary in the early 2010s; Father Heikki Huttunen of the Orthodox Church of Finland who held the position of the General Secretary from 2015 until 2018; and Metropolitan Cleopas Strongylis of the Ecumenical Patriarchate who was elected one of Vice-Presidents at the 2018 Novi Sad General Assembly.

The absence of the Bulgarian and the Russian Orthodox churches from CEC membership, the issue of autocephaly (independence) of the Ukrainian Orthodox Church Kiev Patriarchate which could become the world's second largest Orthodox Church outside Moscow's jurisdiction, are factors which impact upon the Orthodox dialogue with European institutions; at present, most Orthodox faithful are not currently represented in discussion with European institutions. Direct contacts between national representatives of Orthodox churches and European institutions has moved the centre of gravity from ecumenical organisations to a state-based approach in which the lines between national interests and state policies mix with religion. ${ }^{11}$

\section{A symphonia between Orthodox representations and European institutions?}

Orthodox churches lack a commonly-agreed theological doctrine on how to engage with political authorities. Relations between Orthodox churches and the political realm are defined by national cases of church-state relations rather than a supranational policy on political power and state structures. The most widely concept in Eastern Orthodoxy is the Byzantine concept of symphonia which supports close relations between the religious and political entities. Symphonia has remained a contested concept with some scholars arguing that it is closely connected with Caesaro-Papism by enabling state interference in church matters while others argue that it is an obsolete concept, not applicable today, and that the idea of 'partnership' between church and state reflects better current realities. ${ }^{12}$ That symphonia could not be fully applied at EU level is self-understanding. The European Union does not have a pan-European policy on religion and religious issues remain under the jurisdiction of national governments.

When Orthodox churches have made references to symphonia, they were not aiming to change the secular nature of the dialogue with European institutions but to present the uniqueness of Orthodox values. The key concepts of 'authority' and 'legitimacy' in the Eastern

\footnotetext{
${ }^{10} \mathrm{~A}$ full list of CEC members is available at https://www.ceceurope.org/member-churches/ .

${ }^{11}$ Massignon, 'Les représentations orthodoxes auprès de l'Union européenne'.

${ }^{12}$ Meyendorff, The Byzantine Legacy in the Orthodox Church; Anderson, 'Putin and the Russian Orthodox Church'; Knox, 'The Symphonic Ideal'; Hovorun, 'Is the Byzantine 'Symphony' Possible in Our Days?'; Koellner, Orthodox Religion and Politics in Contemporary Eastern Europe; Clark, Why Angels Fall; Clément, L'Église Orthodoxe.
} 
Orthodox world remain disputed between the two main religious actors, namely the Ecumenical Patriarchate and the Russian Orthodox Church. As a fellowship of churches, Eastern Orthodoxy brings together 14 churches in communion, however, there are many other communities, some of which with large number of believers, divided along jurisdictional and geopolitical lines. ${ }^{13}$ The issue of 'canonical territory' between Orthodox churches and the recognition mechanism of acquiring the independent (autocephalous) status continue to be disputed. Both the Ecumenical Patriarchate and the Russian Orthodox Church have advanced their own visions of Europe while the other Orthodox churches have been caught by religious competition with a direct impact upon the ways in which religious representations have engaged in dialogue with European institutions.

The authority of the leader of the Ecumenical Patriarchate, Patriarch Bartholomew, as primus inter pares in the Orthodox commonwealth has been evident in the largest numbers of meetings with top EU officials in Brussels. On 12 May 1993, Bartholomew had a meeting with President Delors; gave a speech to the European Parliament the following year on 19 April 1994; organised an interfaith meeting on 'The Peace of God in the World' attended by Romano Prodi, President of the European Commission, in Brussels on 19-20 December 2001; ${ }^{14}$ met EU officials from the Commission on 13 September 2004; had a meeting with President José Manuel Barroso on 12 July 2005; and gave a second speech to the European Parliament on 24 September 2008. ${ }^{15}$ Despite the significant number of meetings, the Patriarchate has no website to engage with mass media and the general public. In most of his public speeches he emphasised the Patriarchate's work on environmental issues and advocated Turkey's membership of the European Union. Although Bartholomew's position is anticipated due to the status of religious minority at home (around 3,000 believers in Turkey), he stands out in the support for his church from most Orthodox leaders in Eastern Europe and diaspora. The symphonia model presented by the Ecumenical Patriarchate is one which asserts the heritage of Byzantium in the making of contemporary Europe rather than advancing close relations between the religious and political realms.

A contrasting view of symphonia has been evident in the speeches of Russian clergy. From the time of his enthronement, Patriarch Kirill made reference to symphonia as a unique model of church-state relations in the history of Europe. Constitutionally, church-state relations are separated in Russia, however, close association between the two realms have regularly made news headlines. Russia's national security strategy even advances the concept of 'spiritual security' which benefits the Orthodox Church by working closely with state structures. Russia's foreign policy has employed religious channels of communicating political messages and influencing state behaviour in predominantly Orthodox countries. The Russian Orthodox Church's approach of engaging with European institutions has been influenced by the concept of spiritual security. First, Patriarch Kirill has not given any speeches organised by European institutions in Brussels. Second, 'the Representation of the Russian Orthodox Church to the European Institutions' located at the Holy Trinity Church in Brussels has under its remit not only the dialogue with European institutions in Brussels but also with the Council of Europe

\footnotetext{
${ }^{13}$ Thual, Géopolitique de l'Orthodoxie; Papkova, The Orthodox Church and Russian Politics; Richters, The PostSoviet Russian Orthodox Church; Curanović, The Religious Factor in Russia's Foreign Policy; Garrard and Garrard, Russian Orthodoxy Resurgent; Ramet, Nihil Obstat; Pankhurst and Kilp, 'Religion, the Russian Nation and the State'.

14 The declaration is available at https://www.patriarchate.org/patriarchal-documents//asset_publisher/2lzbCNORLysD/content/the-brussels-declaration-the-peace-of-god-in-the-world-towardspeaceful-coexistence-and-collaboration-among-the-three-monotheistic-religions-judaismc? inheritRedirect $=$ false .

15 The speech is available at http://www.europarl.europa.eu/sides/getDoc.do?pubRef=//EP//TEXT+CRE+20080924+ITEM-009+DOC+XML+V0//EN .
} 
in Strasbourg. ${ }^{16}$ The representation acts on both pastoral issues and as a diplomatic hub. On 10 July 2003, when Igor Ivanov, Russia's Minister of Foreign Affairs, travelled to Brussels, he was welcomed by Bishop Hilarion of Vienna and Austria, head of the Representation, who summarised its activities since its establishment a few months before, as follows:

'Close ties have been established between us and the Embassy of the Russian Federation in the Kingdom of Belgium, the Permanent Mission of the Russian Federation to the European Communities, the Permanent Representation of the Russian Federation to the Council of Europe, the respective Embassies and Representations of Belarus, Moldova and Ukraine, the Representations of the Churches of Constantinople and Greece to the European Union as well as Catholic and Protestant organizations'. ${ }^{17}$

That the office matters in the structures of ecclesiastical and political power has been evident when Bishop Hilarion was appointed in charge of the Department of External Relations of the Russian Orthodox Church immediately after Patriarch Kirill's enthronement. Third, and most importantly, Russian clergy have regularly presented Eastern Orthodoxy as an alternative to the secularised West, a pan-Orthodox civilisation opposing the decadent West. ${ }^{18}$

Among the other Orthodox churches, the clergy from the Cypriot, Greek and Romanian Orthodox churches, ${ }^{19}$ have visited Brussels and attended meetings organised by the European Commission as part of the annual dialogue with religious leaders. In all of these cases, the most important result of these meetings was the church image at home. On 30 May 2013, Patriarch Daniel of the Romanian Orthodox Church met Presidents Herman van Rompuy and José Manuel Barroso aiming to reach to the large number of Romanians living in the West after the country's accession to the European Union. Metropolitan Athanasios of Achaia, head of the representation of the Orthodox Church of Greece, attended meetings organised by the European Commission and the European Parliament, ${ }^{20}$ aiming to alleviate criticism between church message and state officials. His view was in contrast with that of Archbishop Ieronymos of Athens who, in 2015 and 2016, criticised the European Union claiming that Brussels aimed to 'de-Christianise' Europe ${ }^{21}$ and that Europe was working to 'alter Christian Greek society and the identity of Greek people'. ${ }^{22}$ Patriarch Filaret of the Ukrainian Orthodox Church - Kiev Patriarchate travelled to Brussels to raise awareness of the military conflict in eastern Ukraine. On 2 May 2018, he attended an international conference on 'The Human Cost of Russian Aggression in Ukraine: Testimonies of Abductions, Torture and Murder' held at the European Parliament and met President Tusk of the European Council. ${ }^{23}$ A few days later, the Ukrainian President Petro Poroshenko appealed to the Ecumenical Patriarchate for recognition of the Ukrainian Church as an independent church outside Moscow's jurisdiction. National interests

\footnotetext{
16 The website of the Russian Orthodox Church Representation to the European Institutions is available at http://orthodoxru.eu/index.php?content=home\&lang=en .

17 The speech is available at http://orthodoxeurope.org/print/19/2/5.aspx .

${ }^{18}$ Makrides, 'The Barbarian West'; Madeley, 'Enigmatic variations: Russia and the three secularities'; Demacopoulos and Papanikolaou, Orthodox Constructions of the West.

19 The website of the Romanian Orthodox Church to the European Institutions is available at http://www.orthodoxero.eu/ .

${ }^{20}$ The website of the Representation of the Orthodox Church of Greece to the European Union is available at http://www.regue.eu/en/ .

${ }^{21} \mathrm{http}: / /$ orthochristian.com/98236.html .

22 http://greece.greekreporter.com/2015/10/07/archbishop-ieronymos-claims-europe-is-against-greek-orthodoxy/

23 Patriarch Filaret's speech is available at https://www.cerkva.info/posts/dopovid-sviatiishoho-patriarkhafilareta-na-konferentsii-u-yevropeiskomu-parlamenti .
} 
have also been present in the activities of the Office of the Orthodox Church of Cyprus which was set up with the specific mission, as follows:

'To draw public attention to the continuing 35-year illegal occupation by Turkish troops of Christian places of worship and other Christian monuments in the north of Cyprus. To provide information about the continuing destruction, desecration and looting of these monuments by the Turkish army of occupation. To provide information about the theft and illegal export of more than 20,000 Byzantine icons, frescoes and other religious relics from the places. ${ }^{24}$

The Representation's work seemed to provide results with a public event in 2011 when the singer Boy George donated an icon back to the Cypriot church. ${ }^{25}$

In addition to direct contact between national representations and European institutions, Orthodox churches have set up a transnational representation titled 'the Committee of Representatives of Orthodox Churches to the European Union' (CROCEU). CROCEU was established on 17 March 2010 by representatives of five churches with offices in Brussels, namely the Ecumenical Patriarchate; the Moscow Patriarchate; the Patriarchate of Romania; the Church of Cyprus; the Church of Greece. In the opening statement, the Committee stated that it aimed to engage in

'dialogue between on the one hand the Churches of different denominations and religious communities sharing common values and on the other hand the EU institutions. The Committee considers dialogue in view of the implementation of Article 17(3) a challenge and an opportunity for promoting the fundamental values and principles upon which European culture has based itself and along which it has developed, such as justice, peace, protection of the environment, sensitivity in front of situations of poverty and suffering, reasonable distribution of financial assets, condemnation and avoidance of all sort of violence, protection of children and women, access to education for all, standing in solidarity with one another, freedom of communication and expression, protection of religious freedom concerning both minorities and majorities and the rule of law'. ${ }^{26}$

A parallel could be drawn between CROCEU and COMECE, the Commission of the Bishops' Conferences of the European Union. COMECE is the official representation of the Catholic faithful in Europe and in direct contact with Catholic bishops across Europe; similarly, CROCEU presents itself as the Orthodox structure representing the Orthodox faithful and with direct support from the hierarchy. By setting up a different mechanism of dialogue with European institutions, Orthodox churches have moved away from Protestant churches and the ecumenical movement highlighting the uniqueness of Eastern Orthodoxy in relation to the secular West. The CROCEU's meetings, both in Brussels and in the capitals of national Orthodox churches, have been held under the umbrella of Orthodox solidarity rather than as part of inter-religious and ecumenical dialogue with European institutions. By holding meetings separately from the Conference of European Churches, CROCEU advances Orthodox

\footnotetext{
${ }^{24}$ The website of the Representation of the Orthodox Church of Cyprus to the European Union is available at http://www.churchofcypruseu.com/index.php/en/ The text has been removed and replaced with photographs of looted buildings.

25 BBC, 'Boy George returns Christ icon to Cyprus church', 19 January 2011, https://www.bbc.co.uk/news/entertainment-arts-12228059.

${ }^{26}$ The communique is available at http://theorthodoxchurch.info/blog/news/communique-of-the-committee-ofrepresentatives-of-orthodox-churches-to-the-european-union/.
} 
exceptionalism and the idea that Eastern Orthodoxy is a unique civilisation reminiscent of Cold War divisions.

\section{Conclusions}

Before President Delors's call to take into account 'spirituality and meaning' in the construction of the European Community, Orthodox churches retained close relations with their counterparts via ecumenical channels in Geneva. The process of European integration and the European Community were regarded as integral elements in ideological clashes between East and West. The Orthodox Church of Greece, the predominant confession of Greece which joined the European Community in 1981, followed a similar perception in the dialogue with European institutions with limited contact the Ecumenical Centre in Brussels. During the Cold War period, encounters between civil servants and Orthodox clergy took place mainly in religious retreats and informally rather than a systematic approach of engaging with European institutions. After the fall of communism, Orthodox churches changed their perception of the European Union. In 1994, the Ecumenical Patriarchate opened the first office of an Orthodox Church in Brussels attempting to represent the whole Orthodox commonwealth. In the subsequent years, other Orthodox churches opened their offices projecting national interests rather than a coherent, transnational position of Eastern Orthodoxy.

Religious competition and the national nature of the Orthodox representations in Brussels led to the establishment of the Committee of Representatives of Orthodox Churches to the European Union in 2010 with Orthodox leaders meeting separately from their ecumenical counterparts. While meetings take place as part of the implementation of Article 17 of the Lisbon Treaty, divisions between Orthodox, Protestant and Catholic leaders enforce the view of Orthodox exceptionalism. In meetings with officials in European institutions, Orthodox leaders have presented issues of national concern, such as education, migrants, cultural heritage, war and religious persecution. The Ecumenical Patriarchate has been the only church to address issues appealing to a transnational audience such as climate change but also of national significance, such as Turkey's membership. The Representation of the Russian Orthodox Church has advanced issues related to the concept of 'spiritual security' by retaining close relations with state structures and acting as a diplomatic hub for the dialogue with institutions in Brussels and Strasbourg. Significant number of Orthodox clergy frequently criticises the project of European integration by placing the Orthodox East in opposition to the Catholic and Protestant West. Religious divisions are reminiscent of the Cold War rhetoric and find support in many countries in Eastern Europe and the former Soviet Union. That Orthodox churches regard their offices in the European Union as centres of ecclesiastical and political power has been evident in the appointment of church hierarchs who occupied positions in Brussels to national hierarchies. It is perhaps in the shaping of early relations between clergy and officials in Brussels that the future of the dialogue between Orthodox churches and European institutions stands. Once returned to their countries, clergy could become veritable ambassadors to the European Union by drawing on their experience of the implementation of Article 17 but also as staunch critics of European policies affecting national interests.

\section{References}

Anderson, John. 'Putin and the Russian Orthodox Church: Asymmetric Symphonia?' Journal of International Affairs, 2007, 61 (1): 185-201.

Byrnes, Timothy A. and Peter J. Katzenstein (eds.). Religion in an Expanding Europe. Cambridge: Cambridge University Press, 2006. 
Cavert, Samuel McCrea. On the Road to Christian Unity: An Appraisal of the Ecumenical Movement. New York: Harper and Row, 1961.

Clark, Victoria. Why Angels Fall: A Portrait of Orthodox Europe from Byantium to Kosovo. London: Macmillan, 2000.

Clément, Olivier. L'Église Orthodoxe. Paris: Presses Universitaire de France, 1985.

Curanović, Alicja. The Religious Factor in Russia's Foreign Policy. London, New York: Routledge, 2012.

Davie, Grace. Religion in Modern Europe: a Memory Mutates. Oxford: Oxford University Press, 2000.

Demacopoulos, George E. and Aristotle Papanikolaou (eds.). Orthodox Constructions of the West. New York: Fordham University Press, 2013.

Foret, François. Religion and Politics in the European Union. The Secular Canopy. Cambridge: Cambridge University Press, 2015.

Fox, Jonathan, Religion and the State: A World Survey. Cambridge: Cambridge University Press, 2008.

Garrard, John and Carol Garrard, Russian Orthodoxy Resurgent: Faith and Power in the New Russia. Princeton: Princeton University Press, 2008.

Hogebrink, Laurens. Europe's Heart and Soul: Jacques Delors' Appeal to the Churches. Brussels: Council of European Churches, 2015.

Hovorun, Cyril, 'Is the Byzantine 'Symphony' Possible in Our Days?' Journal of Church and State, 2016, 59 (2): 280-296.

Koellner, Tobias (ed.), Orthodox Religion and Politics in Contemporary Eastern Europe: On Multiple Secularisms and Entanglements. London: Routledge, forthcoming 2019.

Knox, Zoe. 'The Symphonic Ideal: The Moscow Patriarchate's Post-Soviet Leadership', Europe-Asia Studies, 2003, 55 (4), pp. 575-596.

Kratochvíl, Petr and Tomáš Doležal, The European Union and the Catholic Church. Political Theology of European Integration. Basingstoke: Palgrave, 2015.

Limouris, Gennadios (ed.), Orthodox Visions of Ecumenism: Statements, Message and Reports on the Ecumenical Movement, 1902-1992, Geneva: WCC Publications, 1994.

Leustean, Lucian N. (ed.). Representing Religion in the European Union. Does God Matter?. London: Routledge, 2012.

Leustean, Lucian N. The Ecumenical Movement and the Making of the European Community. Oxford University Press, pp. 69-80. 
Madeley, John, 'Enigmatic Variations: Russia and the Three Secularities', Mirjam Künkler, John Madeley and Shylashri Shankar (eds.), A Secular Age beyond the West. Religion, Law and the State in Asia, the Middle East and North Africa. Cambridge: Cambridge University Press, 2018, pp. 265-94.

Makrides, Vasilios, "The Barbarian West": A Form of Orthodox Christian Anti-Western Critique' in Andrii Krawchuk and Thomas Bremer (eds.), Eastern Orthodox Encounters of Identity and Otherness: Values, Self-Reflection, Dialogue. New York: Palgrave Macmillan, 2014, pp. 141-158.

Massignon, Bérengère, 'Les représentations orthodoxes auprès de l'Union européenne: entre concurrence inter-orthodoxe et dynamiques d'européanisation', Balkanologie. Revue d'études pluridisciplinaires, 2005, 9 (1-2), pp. 265-287.

Meyendorff, John. The Byzantine Legacy in the Orthodox Church. Crestwood, New York: St. Vladimir's Seminary Press, 1982.

McCrea, Ronan. Religion and the Public Order of the European Union. Oxford: Oxford University Press, 2010.

Mey, Peter De. 'An Assessment of the Charta Oecumenica from a Roman Catholic Perspective' in Tim and Ivana Noble, Martin E. Brinkman, Jochen Hilberath (eds.), Charting Churches in a Changing Europe. Charta Oecumenica and the Process of Ecumenical Encounter. Amsterdam and New York: Rodopi, 2006, pp. 17-42.

Mudrov, Sergei A., Christian Churches in European Integration, London: Routledge, 2012.

Nelsen, Brent F. and James L. Guth. Religion and the Struggle for European Union: Confessional Culture and the Limits of Integration, Washington, DC: Georgetown University Press, 2015.

Noris, Pippa and Ronald Inglehart. Sacred and Secular: Religion and Politics Worldwide. Cambridge: Cambridge University Press, 2004.

Pankhurst, Jerry G. and Alar Kilp, 'Religion, the Russian Nation and the State: Domestic and International Dimensions: an Introduction', Religion, State and Society, 2013, 41 (3), pp. 22643

Papkova, Irina. The Orthodox Church and Russian Politics. New York, Oxford: Oxford University Press, 2011.

Patelos, Constantin G (ed.), The Orthodox Church in Ecumenical Movement: Documents and Statements, 1902-1975, Geneva: WCC Publications, 1978.

Richters, Katja. The Post-Soviet Russian Orthodox Church: Politics, Culture and Greater Russia. London. New York: Routledge, 2013.

Ramet, Sabrina P., Nihil Obstat. Religion, Politics, and Social Change in East-Central Europe and Russia. Durham, London: Duke University Press, 1998. 
Stan, Lavinia and Lucian Turcescu, Church, State and Democracy in Expanding Europe. Oxford: Oxford University Press, 2011.

Tsetsis, Georges, Orthodox Thought: Reports of Orthodox Consultations Organised by the World Council of Churches, 1975-1982, Geneva: WCC Publications, 1983.

Thual, François, Géopolitique de l'Orthodoxie, Paris: Dunod, 1993.

Sabev, Todor, The Orthodox Churches in the World Council of Churches: Towards the Future, Geneva: WCC Publications, 1996.

\section{Notes on contributor}

Lucian N. Leustean is Reader in Politics and International Relations at Aston University, Birmingham, United Kingdom. He has been closely associated with IJSCC since his participation in its two Consultations on Orthodox ecclesiology (St George's House, Windsor, Dec. 2009, papers published in IJSCC 11, nos. 2-3 [2011] and University Ecclesiastical Academy of Thessaloniki, Feb. 2012, papers published in IJSCC 12, no. 2 [2012]). He is currently a member of IJSCC's Editorial Advisory Board. His recent publications include, as author, The Ecumenical Movement and the Making of the European Community (Oxford University Press, 2014) and, as editor, Eastern Christianity and Politics in the Twenty-First Century (Routledge, 2014). He is Editor of Routledge's 'Religion, Society and Government in Eastern Europe and the Former Soviet States' series.

\section{ORCID}

Lucian N. Leustean http://orcid.org/0000-0002-1137-2307 